 \\ REVISTA PREVENÇÃO DE INFECÇÃO E SAÚDE (REPIS)
}

\section{Profile of hypertensive pregnant women attending prenatal care in Sobral, Ceará}

\author{
Perfil de gestantes hipertensas atendidas em pré-natal em Sobral, Ceará \\ Perfil de gestantes hipertensas atendidas en prenatal en Sobral, Ceará
}

Bárbara Coelho de Moura Fé ${ }^{1}$, Billy lan Silva Vaz ${ }^{1}$, Yuri Ananias de Vasconcelos ${ }^{1}$, Antônio José de Miranda Dantas Terceiro $^{1}$, José Klauber Roger Carneiro ${ }^{1}$, Maria Auxiliadora Silva Oliveira ${ }^{1}$

1. Centro Universitário Inta - UNINTA, Departamento de Medicina, Sobral, Ceará, Brasil.

\begin{abstract}
Objective: To evaluate the profile of hypertensive pregnant women who underwent prenatal care at a Family Health Center in the city of Sobral/CE in the period 2016/2017. Method: This is a descriptive and documentary analysis study. The charts of parturients attended in the referred CSF (2016 and 2017) were analyzed, analyzing the variables: maternal age, type of delivery, weight of the pregnant woman and cases of hypertension during pregnancy. Results: Fifty-five pregnant women had arterial hypertension and 112 were normotensive; maternal age ranged from 14 to 40 years, predominantly from 21 to 30 years old $(58.9 \%$ in normotensive women and $80 \%$ in hypertensive women). The predominant type of delivery in hypertensive women was caesarean section (80\%). Conclusion: Hypertension is still a major risk factor for the mother and fetus. It was concluded that there was no significant change in the percentage of hypertensive pregnant women when compared to other studies.
\end{abstract}

Keywords: Pregnant women; Hypertension; Risk factor.

\section{RESUMO}

Objetivo: Avaliar o perfil de gestantes hipertensas que realizaram seu pré-natal em um Centro de Saúde da Família (CSF) da cidade de Sobral/CE no período de 2016/2017. Método: Trata-se de um estudo de análise documental e descritiva. Foram analisados os prontuários de parturientes atendidas no referido CSF (2016 e 2017), analisando as variáveis: idade materna, tipo de parto, peso da gestante e casos de hipertensão na gestação. Resultados: 05 gestantes apresentavam hipertensão arterial e 112 eram normotensas, a idade materna variou de 14 a 40 anos, com predominância de 21 a 30 anos (58,9 \% em normotensas e $80 \%$ hipertensas). 0 tipo de parto predominante nas hipertensas foi o cesária (80 \%). Conclusão: A hipertensão arterial constitui-se ainda como um grande fator de risco para gestante e para o feto. Foi possível, assim, concluir-se que não houve uma alteração expressiva na percentagem de gestantes hipertensas em comparação a outros trabalhos.

Descritores: Gestantes; Hipertensão; Fatores de risco.

\section{RESUMÉN}

Objetivo: Evaluar el perfil de gestantes hipertensas que realizaron su prenatal en un Centro de Salud de la Familia del municipio de Sobral/CE en el período de 2016/2017. Método: Se trata de un estudio de análisis descriptivo y documental. Se evaluaron las variables: edad materna, tipo de parto, peso de la gestante y casos de hipertensión en la gestación. Resultados: 5 gestantes presentaban hipertensión arterial y 112 eran normotensas, la edad materna varía de 14 a 40 años, con predominancia de 21 a 30 años (58,9\% en normotensas y $80 \%$ hipertensas). El tipo de parto predominante en las hipertensas fue el cesario (80\%). Conclusión: La hipertensión arterial se constituye como un gran factor de riesgo para la madre y el feto. Se concluye que no hubo una modificación expresiva en el porcentaje de embarazadas hipertensas en comparación con otros trabajos.

Descriptores: Gestantes; Hipertensión; Factor de riesgo.

How to cite:

Fé BCM, Vaz BIC, Vasconselos YA, Terceiro AGMD, Carneiro JKR, Oliveira MAS. Profile of hypertensive pregnant women attending prenatal care in Sobral, Ceará. Rev Pre Infec e Saúde[Internet]. 2019;5:8274. Available from: http://www.ojs.ufpi.br/index.php/nupcis/article/view/8274 DOI: https://doi.org/10.26694/repis.v5i0.8274 


\section{INTRODUCTION}

During pregnancy, the woman and the fetus are exposed to various risks and diseases inherent to the pregnancy. According to data from the WHO (World Health Organization) (2000), every minute is counted the death of a woman in the world due to complications related to pregnancy or childbirth; are 1,600 women/day, almost $600,000 /$ year, with developing countries accounting for the highest percentage, $99 \%$ of these deaths. Most complications and deaths occur during gestation, childbirth and/or puerperium can be avoided, for which it is necessary an active engagement by the health system. ${ }^{1}$

Worldwide, hypertensive pregnancy disorders (HPD) contribute significantly to perinatal morbidity and mortality, accounting for more than 50,000 maternal deaths per year. ${ }^{2}$ In Brazil, something different when compared to developed countries, arterial hypertension in pregnancy continues to be the main cause of direct maternal death. ${ }^{3}$

There are several factors that contribute to the development of DHG, including: age at the extremes of reproductive life, obesity, diabetes, nephropathy, hypertension, family or individual history of preeclampsia or eclampsia, low protein and hypersodium diets, low level of schooling and professional activity, primigravidae, type $A B$ blood group, fetal hydrops, multiple pregnancies and trophoblastic tumor. ${ }^{4}$

Depending on the region, these risk factors, however, may be specific. A study conducted in Brazil ${ }^{5}$ showed that maternal age above 40 years, chronic hypertension and primiparity are the main risk factors for developing hypertension during pregnancy. Another study conducted in India observed that the highest occurrence of Hypertensive Syndromes of Pregnancy (HSP) was among the primiparous, younger mothers and affected in previous pregnancies due to preeclampsia, showing divergences between the different populations studied. ${ }^{6}$

Therefore, the identification of the most important risk factors and comorbidities in the population of the Family Health Center in the municipality of Sobral can be effective in identifying patients who are more likely to develop hypertensive disorders and, subsequently, adequate prenatal care may favor the reduction of this mortality rate.

Reports designed to identify risk factors for hypertensive disorders of pregnancy in our country are scarce. ${ }^{7}$ Therefore, it is important to develop a more detailed study that analyzes the profile of this portion of society.

This study aimed to outline the profile of hypertensive pregnant women who underwent their prenatal care in a Health Center family of the city of Sobral/CE in the years 2016/2017.

\section{METHODS}

The present study was performed at a Family Health Center (FHC) located in the city of Sobral/CE. This is a quantitative, exploratory, retrospective, descriptive study with documentary analysis.

The records of pregnant women $(n=117)$ attended in the aforementioned CSF were analyzed in the years 2016 and 2017. This total $(n=117)$ was of all the women attended in this 
established period. The medical records of different years of this pre-established period were excluded. The data collection was done from the records of pregnant women filed in the Medical Archive and Statistics Service of the referred center.

Variables were analyzed to identify the profile of hypertensive pregnant women: maternal age, type of delivery, nutritional status and cases of hypertension during pregnancy. For the analysis of nutritional status, the BMI (Body Mass Index) was calculated, taking the height squared divided by weight (height $\mathrm{x}$ height / weight). The BMI was the variable classified into 04 groups: pregnant eutrophic, underweight, overweight and obese. According to the Institute of Medicine (IOM), the normal range of $\mathrm{BMI}$, which characterizes eutrophy, corresponds to

\section{RESULTS}

The total number of parturients $(n=117)$ was found in Table 1, 112 normotensive (95.72\%), 5 hypertensive $(4.27 \%)$.

Table 01: Distribution of normotensive and hypertensive pregnant women registered in the records of pregnant women attending in Sobral/CE (2016/2017).

\begin{tabular}{lccc}
\hline & Blood pressure & $\mathbf{n}$ & $\%$ \\
\hline Normotensas & 112 & 9572 \\
Hypertensive & 05 & 4.27 \\
Total & 117 & 100 \\
\hline
\end{tabular}

In addition, Table 2 shows the pregnant women distributed by the age group. It is verified, therefore, that the pregnant women, both hypertensive and normotensive, prevailed in the age group between 21 and 30 years old, being the percentage of normotensive women $58.9 \%$ and hypertensive women $80 \%$. On the Rev Pre Infec e Saúde.2019;5:8274 values of 19.8 to $25.9 \mathrm{~kg} / \mathrm{m} 2 ; \mathrm{BMl}<19.8 \mathrm{~kg} / \mathrm{m} 2$ features low weight; BMl from 26 to $29.9 \mathrm{~kg} / \mathrm{m} 2$ defines overweight and $\geq 30 \mathrm{~kg} / \mathrm{m} 2$ defines obesity. The data were collected from a collection instrument containing the variables analyzed for the medical records of the pregnant women who were seen in center.

The results were presented in tables containing absolute (n) and relative (\%) frequencies, calculated using Microsoft Excell.

The present study was evaluated by the Ethics Committee of the Vale do Acaraú State University, and approved with protocol no. $1,878,614$, following the recommendations of the Ordinance of the National Health Council/MS - CNS, Resolution no.466/12, adopting the four basic principles of bioethics: autonomy, beneficence, non - maleficence and justice.

(n)


Of the total normotensive, $25 \%$ were aged between 14 and 20 years; $58.9 \%$ between 21 and 30 years and $16.07 \%$ between 31 and 40 years. As for the hypertensive, of the total, there were no parturients between the ages of 14 and 20 years; $80 \%$ had ages between 21 and 30 years and 20\% between 31 and 40 years.

Table 02: Distribution of the age group recorded in the charts of normotensive and hypertensive pregnant women attended in Sobral/CE (2016/2017).

\begin{tabular}{lcccc}
\hline \multirow{1}{*}{ Age group } & \multicolumn{2}{c}{ Normotensive } & \multicolumn{2}{c}{ Hipertensive } \\
\cline { 2 - 5 } & $\mathrm{n}$ & $\%$ & $\mathrm{n}$ & $\%$ \\
\hline $\mathbf{1 4 - 2 0}$ years & 28 & 25 & 0 & - \\
$\mathbf{2 1 - 3 0}$ years & 66 & 58.9 & 4 & 80 \\
$\mathbf{3 1 - 4 0}$ years & 18 & 16.07 & 1 & 20 \\
Total & 112 & 100 & 5 & 100 \\
\hline
\end{tabular}

The distribution of normotensive and hypertensive pregnant women in relation to the type of delivery is shown in table 3 . It is noted that the most prevalent birth in normotensive parturients was the vaginal (72.32\%). In hypertensive parturients, the most prevalent type of delivery was cesarean $(80 \%)$.

Table 03: Distribution of the type of delivery recorded in medical records of normotensive and hypertensive pregnant women seen in Sobral/CE (2016/2017).

\begin{tabular}{lcccc}
\hline \multirow{2}{*}{ Tipy of delivery } & \multicolumn{2}{c}{ Normotensive } & \multicolumn{2}{c}{ Hipertensive } \\
\cline { 2 - 5 } & $\mathrm{n}$ & $\%$ & $\mathbf{n}$ & $\%$ \\
\hline Cesarean & 31 & 27.7 & 4 & 80 \\
Vaginal & 81 & 72.32 & 1 & 20 \\
Total & 112 & 100 & 5 & 100 \\
\hline
\end{tabular}

It was possible to analyze, as for the normotensive ones, that $27.7 \%$ performed cesarean delivery and $72.32 \%$ performed vaginal delivery, and for hypertensive women, $80 \%$ performed cesarean delivery and $20 \%$ performed vaginal delivery.
Table 4 shows the distribution of BMI. It was found a higher prevalence of normotensive eutrophic $(43.75 \%)$ and higher prevalence of overweight hypertensive patients $(60 \%)$.

Table 04: Distribution of BMI recorded in medical charts of normotensive and hypertensive pregnant women seen in Sobral/CE (2016/2017).

Weight

Normotensive

n
Hipertensive

\section{Low Weight}

6

$\%$

n

$\%$ 


\begin{tabular}{lcccc}
\hline Normotensive & 49 & 43.75 & 2 & 40 \\
Overweight & 38 & 33.93 & 3 & 60 \\
Obesity & 19 & 16.96 & 0 & - \\
Total & 112 & 100 & 5 & 100 \\
\hline
\end{tabular}

It was verified that, in the case of normotensive parturients, $5.36 \%$ presented low weight; $43.75 \%$ were eutrophic; $33.93 \%$ were overweight and $16.96 \%$ were obese. Among the

\section{DISCUSSION}

Reiterating the findings, the literature describes that hypertensive disorders of pregnancy affect up to $8 \%$ of all pregnancies. ${ }^{7}$ Authors report that hypertensive disorders during pregnancy are considered as main causes of morbidity and mortality in both mother and fetus, thus showing the need to seek knowledge for the prevention of this comorbidity. ${ }^{8}$ The values found in the present study are in agreement with those found in the literature, in which the hypertensive gestational syndromes in developing countries occurred between $2 \%$ and $8 \%$ of the pregnant women, and in Brazil it could reach $30 \% .{ }^{9}$ Differently from what is seen in developed countries, hypertension in pregnancy continues to be the main cause of direct maternal death in Brazil (37\%), with the highest proportions in the Northeast and North regions when compared to the South, Southeast and Midwest. ${ }^{10}$ Hypertensive disorders of gestation affect $7.5 \%$ of Brazilian pregnant women, and in a study in Porto Alegre, during 20 years of observation, they were correlated in $18.5 \%$ of cases of maternal death. ${ }^{2}$

A relationship between hypertension and the age group was observed, which presented Rev Pre Infec e Saúde.2019;5:8274 hypertensive parturients, there were none who presented low weight; 40\% were eutrophic, 60\% were overweight and no hypertensives were obese.

the corresponding age between $21-30$ years ( $80 \%$ of hypertensive patients). Study reported that the sample studied presented a predominance of age between 20 and 30 years (69.23\%), confirming the finding in the present study. ${ }^{11}$

Study carried out in Sorocaba shows that the age group most affected by blood pressure problems would be 25-34 years, revealing social cost and mobility in young people, who already perform social-family activity of great importance as mothers. ${ }^{12}$ It is questioned what would have been the quality of this primary prenatal care, to the point of not being able to recognize the predictability of this pathology specified in the second half of gestation.

Other studies show that the most affected age group is the extremes of age, as is the case of a Brazilian study who reported the gestation of a young woman as well as the pregnancy that occurs in a more advanced age group are considered risk factors for preeclampsia during gestation. Given this, it is important the need for more studies involving the age groups, in order to confirm the existence of age at risk for gestational hypertension. ${ }^{4}$ 
The type of delivery has a great relation with gestational hypertension, whose complications are higher when cesarean delivery occurs in parturients with hypertension, highlighting a greater chance of hemorrhagic complications, infections and hypertensive spikes. The present study showed a relationship between hypertension during pregnancy and the type of cesarean type delivery. This finding is reaffirmed in the literature, as is the case of a study conducted in São Paulo with pregnant hypertensive women, showed that the majority of the patients evolved to cesarean delivery (59.9\%) when compared to natural (vaginal) $(16.0 \%) .{ }^{13}$ In a study carried out in pregnant women hospitalized in a Maternity Hospital, the prevalence of $66.7 \%$ in cesarean type delivery. ${ }^{13}$

In a study performed in Sobral, pregnant women with a history of arterial hypertension or pre-eclampsia are 2.5 times more likely to progress to cesarean delivery when compared to patients who did not have this history. The presence of $\mathrm{HA}$ associated with gestation, in its various clinical forms, is linked to the higher risk of cesarean deliveries. The risk of a caesareantype delivery in patients with pre-eclampsia was twice as high as in those without gestational hypertension. ${ }^{14}$

WHO data from 2011 showed that 53.7\% of deliveries in Brazil are caesarean, the highest rate in the world. Thus, since this high rate of cesarean-type deliveries has considerable clinical and public health importance, any plan to reduce it is valid, including attempted vaginal delivery in parturients with gestational hypertension. ${ }^{15}$
Maternal weight gain is currently a major cause of the increasing prevalence of its associated disorders, one of which is gestational hypertension. Study performed in a maternity hospital in Rio de Janeiro shows that excess weight gain during pregnancy may lead to greater weight gain in the postpartum period, a factor that contributes to the mother's obesity, complicated by subsequent pregnancies, and an increased chance of occurrence gestational diabetes, pre-eclampsia and the need for surgical delivery. ${ }^{16}$

In a review it was concluded that there is evidence that excess weight in the pregestational period is a risk factor for the development of hypertensive diseases during pregnancy. ${ }^{17}$

The inadequate anthropometric status of the mother, both during pregnancy and during pregnancy, is an undisputed public health problem, since it has favored the development of pregnancy intercurrences and influences maternal-concept health conditions during the postpartum period. The literature shows that overweight and obesity during pregnancy are associated with gestational hypertension, chronic hypertension and preeclampsia, and that the risk of preeclampsia is twice as high for every 5 to $7 \mathrm{~kg} / \mathrm{m} 2$ increase in BMl at baseline of the gestational period. Likewise, other studies have associated excessive pregnancy weight gain with a greater risk of developing diabetes, hypertension, obesity, and surgical delivery. ${ }^{18}$

The present study contributes to public health since it showed direct associations with the manifestation of hypertension in pregnant women and the variables analyzed, such as age 
Fé BCM, et al

and weight above the recommended level, as well as the attention and preparation of the team in relation to the outcome for the type of

\section{CONCLUSION}

The results found that hypertension is still a major risk factor for pregnant women and the fetus. It was possible to conclude that there was no significant change in the percentage of pregnant women with hypertension when compared to other studies.

In addition, it was verified that the age of 21 to 30 years, cesarean delivery and weight gain during pregnancy are risk factors for such comorbidity, thus demonstrating the need for greater control and prevention of these factors in order to avoid increased blood pressure and also long-term comorbidity, such as cardiovascular diseases.
Profile of hypertensive pregnant women childbirth, with more prevalent type cesarean for pregnant women with HA.

Another fact that should be emphasized is that there were pregnant women in the age range of 14 and 20 years (although all in the stage of normotensive), meaning that there are young mothers being early. This reality draws attention to the need to invest in public sex education policies directed at this particular public, in order to control the birth rate at a very young age.

In relation to the variable nutritional state, it is concluded that the obesity state is more associated with the presence of hypertension. An accompanying multiprofessional team, including Nutritionist, would be of interest to control weight during gestation

or prevent gain.

\section{REFERENCES}

1. Organização Mundial de Saúde. Diminuindo diferenças: a prática das políticas sobre determinantes sociais da saúde: documento de discussão. Rio de Janeiro: OMS; 2000. Available from:

https: //www.who.int/sdhconference/discussion _paper/Discussion_Paper_PT.pdf

2. Costa SHM, Ramos JGL, Vettori DV, Valério EG. Hipertensão crônica e complicações na gravidez. Rev Socie Cardiol Rio Grande do Sul. [Internet]. 2005 [cited 2017 May 20]; 15(05):1-3. Available

from: http: / /sociedades.cardiol.br/sbcrs/revista/2005/05/Artigo11.pdf

3. Laurenti R, Jorge MHPM, Gotlieb SLD. A mortalidade materna nas capitais brasileiras. Rev Bras Epidemiol [Internet]. 2004 [cited 2018 Apr 20]; 7(4):449-460. Available from: http: / /www.scielo.br/scielo.php?pid=S1415790X2004000400008\&script=sci_abstract\&tlng=pt 4. Moura ERF, Oliveira CGS, Damasceno AKC, Pereira MMQ. Fatores de risco para síndrome hipertensiva da gestação entre mulheres hospitalizadas em pré-eclâmpsia. Rev Ceint América Lat Caribe, Espanha Portugal. 
[Internet]. 2010 [cited 2018 Oct 12]; 15(2):250255. Available

from:

https://revistas.ufpr.br/cogitare/article/view/1 7855

5. Costa HLFF, Costa CFF, Costa LOBF. Idade materna como fator de risco para a hipertensão induzida pela gravidez: análise multivariada. Rev Bras Ginecol Obstet. [Internet]. 2003 [cited 2018 Mar 15]; 25 (9): 631-635. Available from: http://www.scielo.br/pdf/\%0D/rbgo/v25n9/a03 v25n9.pdf

6. Prakash J, Pandey LK, Singh AK, Kar B. Hypertension in pregnancy: hospital based study. JAPI. [Internet]. 2006 [cited 2018 May 15]; 54: 273-278. Available from: https://www.ncbi.nlm.nih.gov/pubmed/169446 08

7. Dalmáz CA, Santos KG, Botton MR, Roisenberg I. Fatores de risco para distúrbios hipertensivos da gravidez no sul do Brasil. Rev Assoc Med Brasileira. [Internet]. 2011 [cited 2017 Nov 29]; 57 (6):692-696. Available from: http: / /www.scielo.br/scielo.php?pid=S0104$42302011000600018 \&$ script=sci_abstract\&tlng=pt 8. Zibaeenezhad MJ, Ghodshi M, Arab P, Gholzom N. The Prevalence of Hypertensive Disorders of Pregnancy In Shiraz, Southern Iran. International Cardiov Jour. [Internet]. 2010 [cited 2017 Oct 25]; 4 (4): 169 - 172. Available from:

https: / /www.researchgate.net/publication/2652 44873_The_Prevalence_of_Hypertensive_Disorde rs_of_Pregnancy_in_Shiraz_Southern_Iran

9. Souza AR, Amorim MR, Costa AAR. Efeitos da ni-fedipina no tratamento anti-hipertensivo da pré-eclâmpsia. Acta Med Port. [Internet]. 2008 [cited 2018 May 12]; 21(4):351-358. Available from:

https://webcache.googleusercontent.com/searc h?q=cache:9j39UPW6zJAJ:https://www.actamed icaportuguesa.com/revista/index.php/amp/artic le $/$ download $/ 796 / 473+\& c d=1 \&$ hl=pt-

BR\&ct $=c l n k \& g l=b r \& c l i e n t=s a f a r i$

10. Laurenti R, Jorge MHPM, Gotlieb SLD. A mortalidade materna nas capitais brasileiras. Rev Bras Epidemiol. [Internet]. 2004 [cited 2017 Oct 25]; 7 (4): 449-460. Available from: http: / / www.scielo.br/scielo.php?pid=S1415790X2004000400008\&script=sci_abstract\&tlng=pt 11. Amadei JL, Merino CG. Hipertensão Arterial e Fatores de Risco em Gestantes Atendidas em Unidade Básica de Saúde. Rev Saúde e Pesquisa. [Internet]. 2010 [2017 Oct 12]; 3(1):33-39. Available

from: http://periodicos.unicesumar.edu.br/index.php /saudpesq/article/view/1330

12. Novo JLVG, Patrício BT, Vanin NS. Hipertensão arterial induzida pela gravidez no Conjunto Hospitalar de Sorocaba. Aspectos maternos e perinatais. Rev Facul Ciências Médicas Sorocaba. [Internet]. 2010 [cited 2018 May 15]; 12(3):9-20. Available from: http://revistas.pucsp.br/RFCMS/article/view/28 39

13. Chaim SRP, Oliveira SMJV, Kimura AF. Hipertensão Arterial na Gestação e condições neonatais ao Nascimento. Acta Paul Enferm. [Internet]. 2008 [cited 2018 May 15]; 21(1):5358. Available from: http: / / www.scielo.br/scielo.php?pid=S0103$21002008000100008 \&$ script $=$ sci_arttext\&tlng=pt 14. Linhares JJ, Macêdo NMQ, Arruda GM, Vasconcelos JLM, Saraiva TV, Ribeiro AF. Fatores associados à via de parto em mulheres com pré- 
Fé BCM, et al

eclâmpsia. Rev Bras Ginecol Obstet. [Internet]. 2014 [cited 2017 Oct 25]; 36(6):259-263. Available from:

http: / / www. scielo.br/scielo.php?pid=S0100-

$72032014000600259 \& s c r i p t=s c i \_a b s t r a c t \& t$ lng=pt

15. Organização Mundial De Saúde. World Health Report - Relatório Mundial de 2005 - faz com que cada mãe e filho contam, Portugal: 2011. Available from: https://www.who.int/whr/2005/media_centre/ overview_pt.pdf

16. Seabra G, Padilha PC, Queiroz JÁ, Saunders C. Sobrepeso e obesidade pré-gestacionais: prevalência e desfechos associados à gestação. Rev Bras Ginecol Obstet. [Internet]. 2011 [cited 2018 May 15]; 33(11):348-353. Available from: http: / /www.scielo.br/scielo.php?pid=S0100$72032011001100005 \&$ script=sci_abstract\&tlng=pt
Profile of hypertensive pregnant women

17. Cidade DG, Margotto PR, Peraçoli JC. Obesidade e sobrepeso pré-gestacionais: Prevalência e principais complicações maternas. Comuni Ciências Saúde. [Internet]. 2011 [cited 2018 May 15]; 22(Sup 1):169-182. Available from: http: / / www.scielo.br/scielo.php?pid=S0100$72032011001100005 \&$ script=sci_abstract\&tlng=pt 18. Gonçalves CV, Cesar JA, Mendoza-Sassi RA, Castro NB, Medi APB. Índice de massa corporal e ganho de peso gestacional como fatores preditores de complicação e do desfecho da gravides. Rev Bras Ginecol Obstet. [Internet]. 2012 [cited 2017 Oct 25]; 34(7):304-309. Available from: http://www.scielo.br/pdf/rbgo/v34n7/03.pdf.

Submitted: 2019-01-25

Accepted: 2019-02-22

Published: 2019-06-01

\section{COLLABORATIONS}

$\mathrm{BCMF}$ and BISV contributed in the data collection and writing of the article. YAV and JMDT contributed to the collection, analysis and interpretation of the data. JKRC contributed in the critical review of the article. MASO contributed to the data collection and critical review of the article. All authors agree and are responsible for the contents of this version of the manuscript to be published.

\section{ACKNOWLEDGMENTS}

Does not apply.

\section{CONFLICTS OF INTEREST}

The authors declare that no have conflicts of interest. 
Fé BCM, et al

Profile of hypertensive pregnant women

\section{AVAILABILITY OF DATA}

Available upon request to the authors.

\section{FUDING SOURCE}

Does not apply.

\section{CORRESPONDENCE}

Bárbara Coelho de Moura Fé

Centro Universitário Inta- UNINTA. R. Cel. Antonio Rodrigues Magalhães, 359, Sobral, Ceara, Brasil Telephone: Bárbara Coelho de Moura Fé

E-mail: myresearchbio@gmail.com 